\title{
Late-glacial and Holocene palaeoenvironments in the Baltic Sea based on a sedimentary record from the Gdansk Basin
}

\author{
Andrey Grigoriev ${ }^{1}$, Vladimir Zhamoida ${ }^{1, *}$, Mikhail Spiridonov $^{1}$, Alla Sharapova ${ }^{1}$, \\ Vadim Sivkov $^{2}$, Darya Ryabchuk ${ }^{1}$
}

\author{
${ }^{1}$ Russian Research Geological Institute (VSEGEI), 74 Sredny Prospect, 199106 St. Petersburg, Russia \\ ${ }^{2}$ Atlantic Branch of P. P. Shirshov Institute of Oceanology (AB IO RAS), 1 Prospect Mira, 236000 Kaliningrad, Russia
}

\begin{abstract}
The focus of this study was the $11.55 \mathrm{~m}$ long sediment core 303700-7, which was retrieved from the Gdansk Basin during a cruise of RV 'Poseidon' within the frame of the Russian-German Project GISEB. The core was analysed for grain size, elemental chemical composition, organic carbon and palynological spectra. The age control was based on palynostratigraphy and 7 radiocarbon datings of bulk sedimentary organic matter. These data provide a high-resolution record of climatic and marine palaeoenvironments in the Gdansk Basin for the last ca. $13 \mathrm{kyr}$, from the Bølling to late Holocene time. Sedimentation rates were estimated to vary between 0.37 and $1.62 \mathrm{~mm} \mathrm{yr}^{-1}$. Major variations in palaeosalinity were estimated from bromine concentrations in the sediment. This method allows the first quantitative reconstruction of palaeosalinity changes in the Baltic Sea, especially profound during the Littorina and Postlittorina periods (middle to late Holocene). In addition, grain size data indicated several Littorina transgressive-regressive stages and a few episodes of increased near-bottom current activity. Our results from the Gdansk Basin are consistent with palaeoceanographic data from other deep basins of the Baltic Sea and provide new insights into the regional Holocene history.
\end{abstract}

KEY WORDS: Environmental changes - Late Pleistocene - Holocene - Baltic Sea sediments • Gdansk Basin · Multiproxy analysis · Palaeosalinity

\section{INTRODUCTION}

After the retreat of the Weichselian ice sheet, ca. $14000 \mathrm{yr}$ BP, the Baltic Sea underwent several stages of development from a freshwater ice-lake to a semi-enclosed brackish-water sea. Such development was a result of climatic change, gradual melting of the ice sheet, eustatic sea level rise and glacio-isostatic uplift of the Baltic Shield (Nilsson 1970, Gudelis \& Emelyanov 1976, Krog 1979, Björck 1995, Blazhchishin 1998, Jensen et al. 1999). The ongoing climatic warming and sea level rise evoke a new marine transgression in the southern Baltic Sea, where the calculated rate of sea level rise is estimated to be about $1.7 \mathrm{~mm} \mathrm{yr}^{-1}$ (HELCOM 2007), which will likely cause an increase in saline North Sea water inflow and related environmental changes. Understanding of these changes requires a knowledge of regional palaeoclimatic and palaeoceanographic history, especially during the current interglacial. Sediment cores from the deepest basins of the Baltic Sea are optimal for such investigations, as they potentially contain uninterrupted Late Pleistocene-Holocene sedimentary records.

The Gdansk Basin is a large sea-floor depression located in the south-eastern Baltic Sea and partly separated by the Gotland-Gdansk Threshold. Palaeoceanographic reconstructions based on the study of the Gdansk Basin sediment cores in the 1970s-1980s are presented in publications of Blazhchishin (1998) and Emelyanov (2002). Relative ages of sediments were 
estimated by means of litho- and chemostratigraphy. Palaeosalinities were evaluated by the method of 'equivalent boron' (Blazhchishin 1982). More recently, chronostratigraphy for some sediment cores from the Gdansk Basin was developed using radiocarbon dating and palynological analysis (Zachowicz 1995, Zachowicz et al. 2008).

In this paper, we present new data on climate-related palaeoenvironmental history of the Gdansk Basin. Reconstruction of regional climatic changes as reflected in the sedimentary record during the period of BøllingMiddle Dryas to Subatlantic time is based on palynological analysis. Changes in sedimentation patterns related to the hydrodynamic regime were evaluated from grain size. Concentrations of bromine $(\mathrm{Br})$ in sediments were measured as a proxy to bottom-water palaeosalinity. This proxy method, combined with earlier data on diatom stratigraphy (e.g. Blazhchishin et al. 1974, Witkowski 1994, Andrén 1999), allows for the first quantitative reconstruction of palaeosalinity changes in the Baltic Sea, which were especially profound during the Littorina and Postlittorina periods.

\section{MATERIALS AND METHODS}

Gravity core 303700-7 was retrieved during a cruise of RV 'Poseidon' in June 2005 within the framework of the Russian-German Project GISEB (GIS for Time/ Space Modelling of Sediment Distribution as a Function of Changing Environment in the Baltic Sea). The coring site is located in the south-eastern part of the Gdansk Basin (54²49.34' N; $19^{\circ} 11.1^{\prime} \mathrm{E}$; water depth 105 m; Fig. 1). The gravity core was investigated along a length of $11.55 \mathrm{~m}$ (80 to $1235 \mathrm{~cm}$ core depth) exclud-

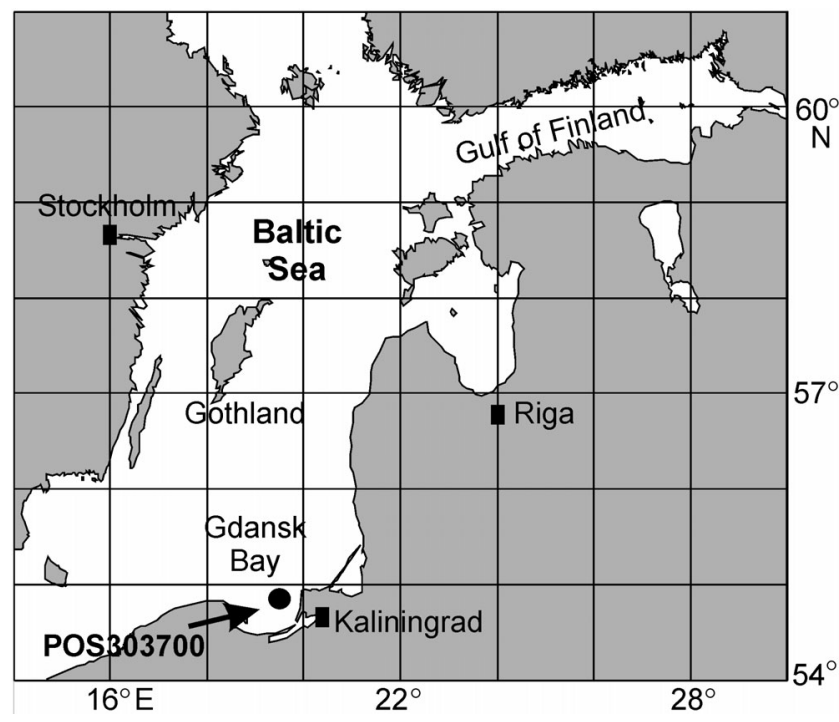

Fig. 1. Coring site (arrow) in the Gdansk Basin ing the fluidised top $80 \mathrm{~cm}$. Multi-corer samples from the same site were used for the uppermost part of the sediment record (0 to $57 \mathrm{~cm}$ ).

Visual descriptions of the core and pollen analyses were made at the Russian Research Geological Institute (VSEGEI). Sediment samples $(\mathrm{n}=140)$ for pollen analysis were taken at $8 \mathrm{~cm}$ intervals. Pollen analysis was performed following the standard technique (Gritchuk \& Zaklinskaya 1948). For each sample, 500 arboreal pollen grains were counted at a magnification of $500 \times_{i}$ nonarboreal pollen and spores were also tallied. The pollen-spore diagram was completed by means of TILIA and TILIA-GRAPH software (Grimm 1990). Percentages of each taxon were calculated per total amount of pollen and spores. Pollen assemblage zones were defined according to the international rules for zonal subdivision (Salvador 1994). The interpretation was based on palaeovegetation ecology and comparison with Quaternary palynostratigraphy studied in the Baltic Sea region (e.g. Nilsson 1964, Stelle et al. 1976, Kleymenova et al. 1979, Malyasova \& Spiridonova 1983, Yakubovskaya et al. 1983, Zachowicz 1995, Emelyanov 2002, Zachowicz et al. 2008).

Radiocarbon dating of sediments ( 7 samples) using dispersed organic carbon was performed at the Centre for Isotopic Research of VSEGEI using an ultra-low level scintillation counter (Quantulus 1220). Radiocarbon data were converted into calibrated ages using Calib 5.0 (www.calib.qub.ac.uk/calib) and the Marine04 curve (Hughen et al. 2004).

Samples for grain size analysis were taken in order to characterise major lithostratigraphic units. Grain size analysis of sediments (100 samples) was carried out at the Atlantic Branch of the P. P. Shirshov Institute of Oceanology (AB IO RAS) using a Fritsch laser analyser ('Analysette-22', 0.001 to $0.1 \mathrm{~mm}$ ) and a Fritsch analytical sieve shaker ('Analysette-3', $0.1 \mathrm{~mm}$ ). Organic matter was eliminated from the analysed samples by soaking them in a solution of $\mathrm{H}_{2} \mathrm{O}_{2}$. Grain size data were processed by means of Analysette 22 32-Bit software.

Total organic carbon (TOC) analysis was performed on 66 samples at the AB IO RAS using an expressanalyser (AN-7529M). Samples for TOC analysis were taken at $8 \mathrm{~cm}$ intervals between 80 and $606 \mathrm{~cm}$ core depth.

Sediment samples for geochemical analysis were taken at $8 \mathrm{~cm}$ intervals. Measurements of bulk $\mathrm{Br}$ concentrations were performed at VSEGEI on 140 sediment samples using an X-ray scanning crystaldiffractive spectrometer (SPEKTROSKAN-005). Prior to analysis, the samples were dried at $20^{\circ} \mathrm{C}$ and ground. Br concentration in sediment was applied for the first time as a palaeosalinity proxy. This method was developed at VSEGEI based on the estimate of 
behaviour affinity of $\mathrm{Cl}$ and $\mathrm{Br}$ and a stable $\mathrm{Cl}: \mathrm{Br}$ ratio of 230 in the water column and in pore waters of Baltic Sea sediments (Shishkina et al. 1969) and the assumption that this ratio remained fairly stable during sediment accumulation even in freshwater environments. This assumption was experimentally confirmed by the comparison of actual (Terziev 1994, Shabaev et al. 2008) and Br-estimated salinity in sediments of the freshwater $(<1 \%)$ southern part of the Curonian Lagoon and brackish-water eastern Gulf of Finland. The Brbased salinity (S) can be estimated using the empirical formula $\mathrm{S} \%$ o $=0.115+1.80655 \times(\mathrm{Br} \%$ o $-0.0046 \%$ o $) \times 230$, which was modified from the Cl-based formula $\mathrm{S} \%=$ $0.115+1.80655 \mathrm{Cl} \%$ o used by Snezhinsky (1951) and Lyahin (1994). The constant value of $0.0046 \%$ was determined as a regional background $\mathrm{Br}$ concentration in the minerals of silty-clayey sediment accumulated in freshwater basins. We note that $\mathrm{Br}$ can also be sorbed by organic carbon in particulate matter. A noticeable correlation was found between the downcore distribution of $\mathrm{Br}$ and TOC concentrations measured in core 303700-7 sediments between 80 and $606 \mathrm{~cm}$, which implies the possibility that $\mathrm{Br}$ distribution is partially controlled by the TOC concentration. Nevertheless, estimated salinities based on $\mathrm{Br}$ concentrations measured in 13 samples of organic-rich, silty-clayey surficial $(0$ to $5 \mathrm{~cm})$ sediments of the freshwater southern part of the Curonian Lagoon (near 1\%o salinity, 5 to $10 \%$ TOC; TOC concentrations from Emelyanov 2002) and the brackish-water eastern Gulf of Finland (4 to $8 \%$ salinity, 3 to $6 \%$ TOC) and show a very good correspondence to near-bottom water salinities (Terziev 1994, Shabaev et al. 2008) in these areas.

\section{RESULTS AND DISCUSSION}

\subsection{Lithostratigraphy}

A visual description of the core enabled us to distinguish 4 major lithostratigraphic units similar to those distinguished earlier by Blazhchishin (1998):

Unit 1 (1135 to $1235 \mathrm{~cm}$ ): dense, grey clay containing small lenses and thin laminae enriched in silt particles. This unit corresponds to the Baltic Ice Lake period.

Unit 2 (835 to $1135 \mathrm{~cm}$ ): light-grey, silty, less dense clay containing small lenses and thin laminae enriched in silt-sand particles, especially common at a core depth of 1007 to $1008 \mathrm{~cm}$ (Fig. 2). Blazhchishin (1998) and Uscinowicz (2003) suggested that such sediment facies enriched in sand particles were formed as a result of the Baltic Ice Lake drainage during the Allerød and Younger Dryas.

Unit 3 (644 to $835 \mathrm{~cm}$ ): grey, sometimes black, silty clay with black micro-inclusions of amorphous iron-

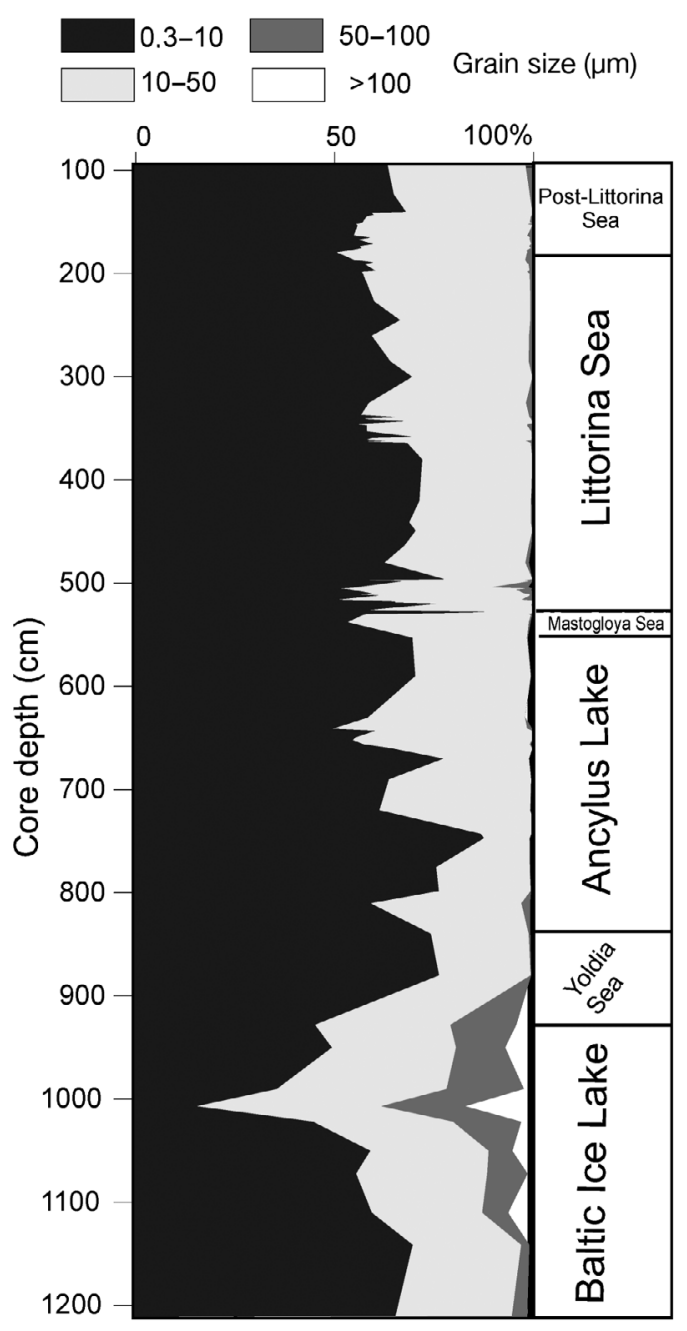

Fig. 2. Sediment grain size distribution in core 303700-7

sulphides. This sediment is believed to have formed during the Ancylus Lake and Yoldia Sea period (Blazhchishin 1998, Emelyanov 2002).

Unit 4 (644 to $0 \mathrm{~cm})$ : laminated, olive-grey, siltyclayey sediment, locally porous and containing shell fragments. This interval was accumulated during the Late Holocene, Littorina and Post-Littorina stages.

\subsection{Radiocarbon ages}

Seven radiocarbon ages (Table 1) were obtained on bulk organic matter from sediments mainly above $650 \mathrm{~cm}$ core depth, which have relatively elevated content of organic carbon of 1.5 to $6.8 \mathrm{wt} \%$. Radiocarbon ages obtained yielded extrapolated linear sedimentation rates of 0.37 to $1.62 \mathrm{~mm} \mathrm{yr}^{-1}\left(0.84 \mathrm{~mm} \mathrm{yr}^{-1}\right.$ average). 
Table 1. Radiocarbon dating ( \pm range) (years before 1950) of gravity core 303700-7, collected in the Gdansk Basin

\begin{tabular}{lrc} 
Sediment depth $(\mathrm{cm})$ & C $^{14}$ years BP & Calibrated years BP \\
\hline $200-205$ & $4710 \pm 130$ & $5136-4814$ \\
$258-270$ & $5080 \pm 130$ & $5574-5297$ \\
$298-310$ & $5750 \pm 120$ & $6277-6013$ \\
$377-390$ & $6450 \pm 150$ & $7135-6779$ \\
$480-495$ & $7110 \pm 200$ & $7785-7417$ \\
$620-635$ & $8520 \pm 130$ & $9318-8993$ \\
$1040-1060$ & $11800 \pm 500$ & $13839-12826$
\end{tabular}

\subsection{Pollen spectra and palynostratigraphy}

Palynomorphs from the surface sediment sample (0 to $5 \mathrm{~cm}$ ) were characterised by the predominance of trees (93\%), including Pinus sylvestris (61\%), Betula sect. Albae (19\%), Alnus spp. (7\%) and Picea abies (4\%), with rare occurrences of Salix, Corylus, Tilia, Ulmus, Fagus and Quercus. Poaceae, Chenopodiaceae and Artemisia spp. dominated among the herbs (5\% of the total spectrum), and Polypodiaceae dominated among the spores (2\%).

Based on the distribution of Quaternary pollen and spores, we distinguished 10 pollen assemblage zones (PAZ) corresponding to climatic events of the BlyttSernander scale (Mangerud et al. 1974) (Table 2, Fig. 3). Redeposited Late Cretaceous-Palaeogene and Neogene palynomorphs (Gleichenia, Taxodium, Ilex, Rhus and pollen of the Normapolles group) were found in concentrations ranging between 2 and $18 \%$ below $793 \mathrm{~cm}$ in core depth and only sporadic occurrences in younger sediments.

The lower maximum of Artemisia and increased abundance of Betula sect. Nanae in PAZ 1 (BøllingMiddle Dryas) reflect a periglacial-tundra vegetation characteristic of cold and dry climate. The pollen assemblage of PAZ 2 (Allerød) indicates climatic amelioration and is characterised by a shift from periglacial-

Table 2. Comparison of pollen assemblage zones (PAZ) and climatic events after BlyttSernander (Mangerud et al. 1974)

\begin{tabular}{|lccc|}
\hline PAZ & $\begin{array}{c}\text { Sediment } \\
\text { depth }(\mathrm{cm})\end{array}$ & Index pollen forms & Climatic events \\
\hline 10 & $0-99$ & Pinus - Fagus & Subatlantic \\
9 & $99-246$ & Pinus - Betula sect. Albae - Picea & Subboreal \\
8 & $246-350$ & Pinus - Quercetum mixtum & Late Atlantic \\
7 & $350-520$ & Pinus - Alnus - Quercetum mixtum & Early Atlantic \\
6 & $520-704$ & Pinus & Boreal \\
5 & $704-793$ & Pinus-Polypodiaceae & Late Preboreal \\
4 & $793-880$ & Pinus - Betula sect. Albae & Early Preboreal \\
3 & $880-1065$ & Betula sect. Nanae-Artemisia & Younger Dryas \\
2 & $1065-1135$ & Pinus - Betula sect. Albae-Sphagnum & Allerød \\
1 & $1135-1236$ & Betula sect. Albae-Betula sect. Nanae-Artemisia & Bølling-Middle Dryas \\
\hline
\end{tabular}

tundra to tundra vegetation with some influence from a forest-tundra coenosis developed farther south. Temperature decreased again during the Younger Dryas (PAZ 3), resulting in the re-advance of periglacial-tundra vegetation with maxima of Betula sect. Nanae and Artemisia. The pine pollen found in this zone were characterised by smaller size and poor quality. The Preboreal climatic warming (PAZ 4 and 5) resulted in the tree-line advance. At the boundary between PAZ 5 and 6, the concentration of Quaternary pollen and spores sharply increased from 23-51 to 218-1080 grains $\mathrm{g}^{-1}$ due to a prolific development of pine forests particularly during the Boreal warming. The Holocene climatic optimum can be identified as the first stage of the Atlantic Chronozone (PAZ 7). This pollen assemblage suggests a maximum advance of deciduous forests with the predominance of oak, elm, lime-tree, and hazel. The northern range of these forests was situated farther north than at present. At the end of the Atlantic (PAZ 8), the climate became colder, and the area of deciduous forests decreased. In the Subboreal (PAZ 9), the retreat of deciduous forests continued; however, higher than recent concentrations of Quercus and Tilia pollen indicate that the climate was still warmer than at present. In the Subatlantic (PAZ 10), a further decrease in deciduous tree pollen and the increase in herbaceous pollen indicate a colder climate.

\subsection{Br concentrations and estimated palaeosalinity}

Distribution of palaeosalinities estimated from Br concentration (Fig. 4) enabled us to distinguish several stages of the Baltic Sea development. The lower part of the core up to $711 \mathrm{~cm}$ depth is characterised by uniformly low $\mathrm{Br}$ concentration and low estimated salinity ( 2 to $3 \%$ ). The sediments of this interval probably constitute the Baltic Ice Lake and Ancylus Lake until the end of the Early Preboreal. Hence we assume that the Yoldia Sea, which existed towards the end of the Younger Dryas in the Gdansk Basin, was characterised by fresh water with increased electric conductivity (i.e. very weakly brackish water), rather than being true brackish water as observed in the Gotland Basin (e.g. Sohlenius et al. 1996, Emeis et al. 2003). This interpretation is consistent with results of the diatom analysis from e.g. Kessel et al. (1973), Blazhchishin et al. (1974) and Abelmann (1985). A higher 


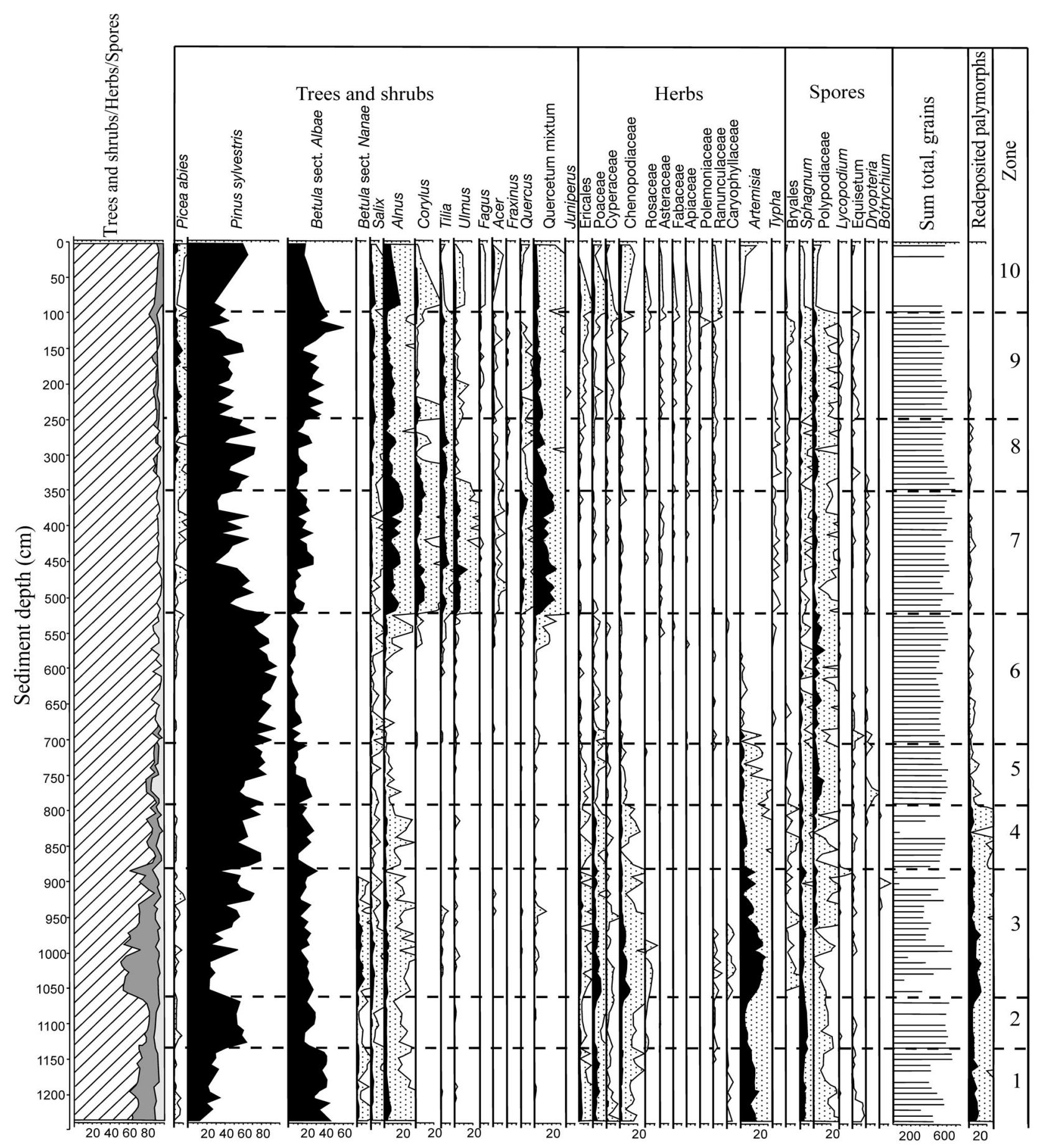

Fig. 3. Pollen and spore percentage diagram of core 303700-7. x-axis values are \% of total pollen and spores; except sum total, grains $=\mathrm{n}$. In the left-most panel, diagonal hatching $=$ trees and shrubs, dark grey shading $=$ herbs, and light grey shading $=$ spores. In the rest of the panels that show percentages, the black shaded curves are the actual \% value, the dot shaded curves show the $10 \times$ exaggeration of the percentages

salinity event (4\%) occurred at 765 to $790 \mathrm{~cm}$, at the boundary between the Early and Late Preboreal, ca. 9200 yr BP based on linear interpolation between available ${ }^{14} \mathrm{C}$ ages (Fig. 4). From 701 to $549 \mathrm{~cm}, \mathrm{Br}$ concentration increased from 0.001 to $0.0015 \%$, corresponding to a palaeosalinity rise up to $5 \%$. This may indicate increasing water exchange with the ocean.
This interpretation confirms Blazhchishin's (1998) inference that the Ancylus Lake at the late stage of its development was already characterised by brackishwater conditions. Above $549 \mathrm{~cm}$ core depth, estimated palaeosalinities showed a distinct increase, up to $9 \%$, indicating a major change from freshwater (lacustrine) to brackish-water (marine) conditions that probably 


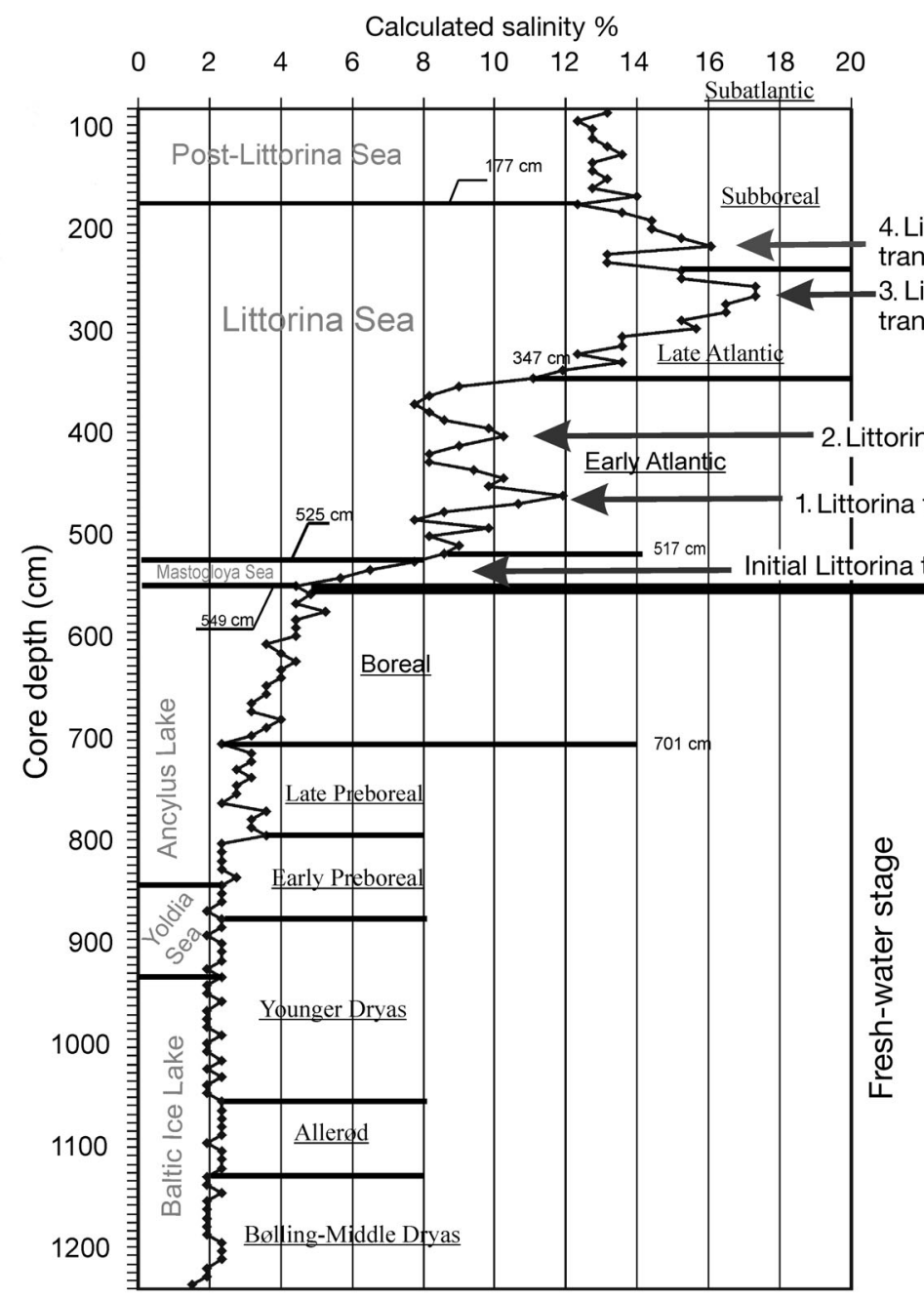

occurred during the Littorina transgression. Linear interpolation of radiocarbon ages constrains the beginning of this event in the Gdansk Basin to ca. $7700{ }^{14} \mathrm{C}$ yr BP. About 8000 to 8500 yr BP, the North Sea water started to intrude through the Danish straits into the Baltic Sea due to the eustatic sea level rise (Berglund 1964, Gudelis \& Emelyanov 1976, Krog 1979, Bitinas \& Damusyte 2004, Berglund et al. 2005). Some authors distinguish this stage as the Mastogloia Sea (Eronen 1983). The end of this stage can be identified in core $303700-7$ by stabilisation of salinity at $509 \mathrm{~cm}$, ca. $7340 \mathrm{yr}^{14} \mathrm{C}$ BP. A similar age of ca. 7500 yr BP was suggested as the beginning of the Littorina Sea stage by Uscinowicz (2003).

Our data point out 4 significant salinity maxima during the Littorina Sea stage (Fig. 4). Two of them occurred during the Early Atlantic time at a core depth of 461 to $462 \mathrm{~cm}$ (ca. $6700{ }^{14} \mathrm{C}$ yr BP, $0.0033 \% \mathrm{Br}$, salinity: $12 \%$ ) and 403 to $404 \mathrm{~cm}$ (ca. $6475{ }^{14} \mathrm{C}$ yr BP, $0.0029 \% \mathrm{Br}$, salinity: $10.3 \%$ ). The highest salinity value was identified in the interval dated to the Late Atlantic
Fig. 4. Palaeosalinity calculated from the bromine concentration in core 303700-7 time (259 to $268 \mathrm{~cm} ; 5080{ }^{14} \mathrm{C}$ yr BP) with a Br concentration of $0.0046 \%$ and estimated salinity of $17 \%$. The youngest salinity maximum (16\%) was recorded at a core depth of $217 \mathrm{~cm}$. It occurred during the beginning of the Subboreal period (ca. $4640{ }^{14} \mathrm{C}$ yr BP). The salinity maxima identified in core $303700-7$ in sediments of the Atlantic and Subboreal can be correlated with the 4 marine transgression stages, consistent with geological data from other areas of the Baltic Sea. A record of 4 to 6 Littorina Sea transgressions was found in Sweden (Berglund 1964, Berglund et al. 2005, Yu et al. 2005), 3 in Lithuania (Bitinas \& Damusyte 2004) and 4 in Germany (Lampe \& Janke 2004).

The end of the Littorina Sea period was characterised by a significant decrease in water salinity caused by reduced marine water inflow due to isostatic uplift in the area of the Danish straits (Blazhchishin 1998, Eronen et al. 2001, Gelumbauskaite \& Šeckus 2005). A significant salinity decrease was identified in core $303700-7$ above $217 \mathrm{~cm}$ with a minimum of $12 \%$ at 177 to $178 \mathrm{~cm}$ (ca. $4200{ }^{14} \mathrm{C}$ yr BP). In sediment above this interval, $\mathrm{Br}$ concentrations and, thus, estimated salinity remained relatively stable. This corresponds to the environments of the Post-Littorina stage of the Baltic Sea development.

\subsection{Grain size fractionation and bottom current activity}

It is assumed that the grain size parameters (e.g. mean size, sorting, skewness, mode) of fine-grained sediments reflect the velocity of the bottom current transporting suspended sediments. In conditions of relatively deep-water areas of silty-clayey mud accumulation, the grain size distribution of sediments is controlled mainly by so-called 'fractionation during 
deposition' of suspended sediment. A higher bottom current velocity causes increases in silty-particle amounts and prevents deposition of the finest particles (McCave 1984-1985). A silty mode size of suspended sediment varies from 20 to $100 \mu \mathrm{m}$. Deposition of clay and fine silt mode are suppressed under bottom currents; therefore, the fine-silty grain size fraction (10 to $20 \mu \mathrm{m}$ ) is mostly sensitive to variations in bottom current velocity (McCave 1985).

It must be taken into account that inference of temporal variation in the current velocity based upon downcore grain size analysis may be ungrounded if the sediment load composition was essentially changed during the period of sediment accumulation. However, the assumed stability of sediment load in the Gdansk Deep enables reconstruction of changes in the bottom current activity during the Late Holocene using sediment grain size parameters.

The deep-water circulation in the Baltic Sea to a certain extent depends on the North Sea water inflows (e.g. Matthäus \& Franck 1992). The bottom current velocities usually do not exceed a few $\mathrm{cm} \mathrm{s}^{-1}$. Increased current velocities in the Baltic Sea deeps take place during saline water inflows from the North Sea (Pedersen 1977, Stigebrandt 1987).

According to the sediment grain size indices, 3 episodes of bottom current activity increases can be distinguished in the Gdansk Basin during the Late Holocene (Fig. 5). The first episode practically coincides with the Mastogloia Sea stage with significant (up to $9 \%$ ) salinity increase. The second is correlated with activation of the Littorina transgression during the late Atlantic Chronozone and salinity increase (up to $12 \%$ o). The last episode of bottom current activity is related to the regression and palaeosalinity decrease from 16 to $13 \%$, which occurred at the end of the Littorina stage.

\section{CONCLUSIONS}

Our study of the sedimentary record from the Gdansk Basin covers the time interval of the Late Pleistocene and the whole Holocene. Results of the multiproxy approach to the sediments of the Gdansk Basin allowed us to conclude that climate is the major driving force responsible for the environmental changes and salinity of the Baltic Sea waters in particular. We also showed that the sedimentary record of the Gdansk Basin conforms very well with environmental changes which took part over the time period in question in the whole Baltic Sea Basin. In particular, we were able to show that:

(1) Ten pollen assemblage zones distinguished in accordance with the Blytt-Sernander scale (supported

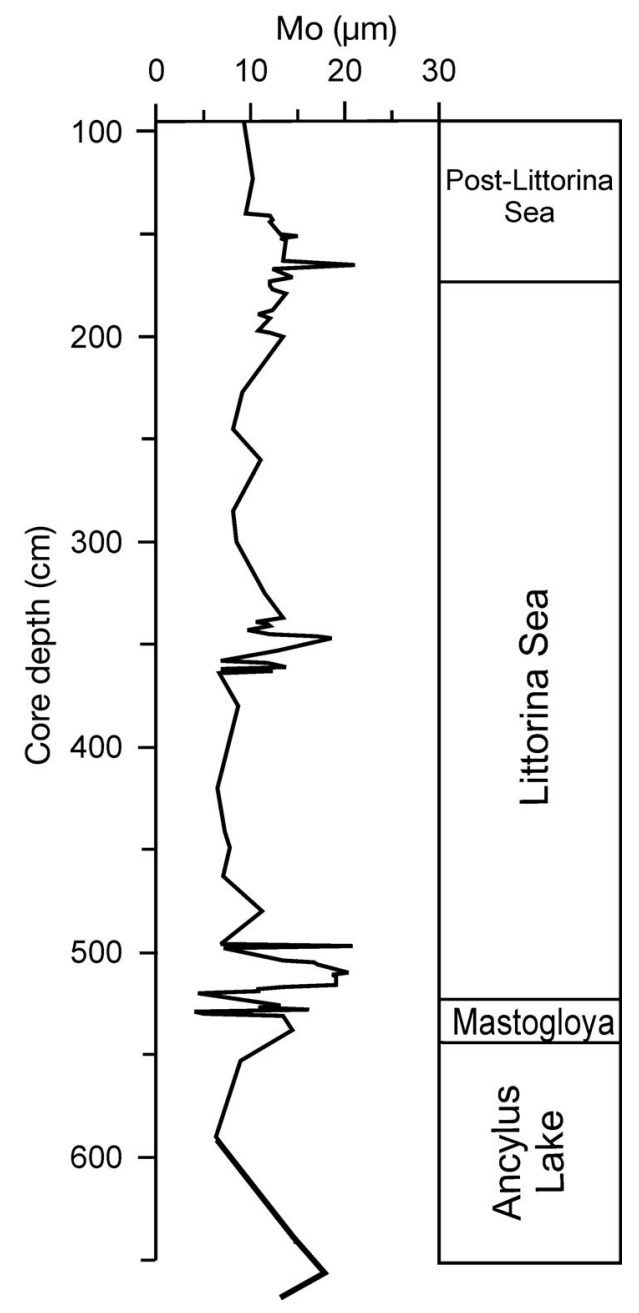

Fig. 5. Sediment modal grain size (Mo) in depth interval 100 to $660 \mathrm{~cm}$ of core 303700

by radiocarbon datings) represent a good tool for reconstructing palaeovegetation development. It seems that this is the best proxy for reconstructing climatic changes during the periods of Bølling-Middle Dryas to Subatlantic in the Gdansk Basin and its surroundings.

(2) Results of our study support the 4-stage development scenario of the Gdansk Basin (Baltic Sea). Radiocarbon datings and pollen analysis enabled us to set the boundaries between particular Baltic Sea development stages.

(3) The average rate of sedimentation during the Late Pleistocene - Holocene amounted to $0.84 \mathrm{~mm} \mathrm{yr}^{-1}$ and ranged from 0.37 to $1.62 \mathrm{~mm} \mathrm{yr}^{-1}$.

(4) From the Baltic Ice Lake to the end of the Ancylus Lake development, the sediments were characterised by stable $\mathrm{Br}$ concentrations and a calculated salinity of about $2 \%$. The Yoldia Sea stage sediments of the Gdansk Basin did not reveal increases in palaeosalinity. 
(5) The beginning of the Littorina Sea (Mastogloia Sea) was characterised by a distinct increase of Br concentrations and a calculated salinity up to $9 \%$, which corresponds to the change from freshwater (lacustrine) to brackish-water (marine) conditions.

(6) The Littorina Sea development was characterised by 4 maxima of salinity as a result of the influence of marine transgressions. The maximum palaeosalinity (up to $17 \%$ ) was inferred in the sediments of the Atlantic Chronozone.

(7) Analysis of the grain size distribution of the Holocene sediments allowed us to distinguish 3 episodes in the Gdansk Deep which coincide with transgressiveregressive cycles of the Baltic Sea development.

Acknowledgements. This study was financially supported by the Department of Mineral Resources of the North-West Federal Region of the Russian Federation (Sevzapnedra). We thank the coordinators of the GISEB Project, i.e. J. Harff and E. M. Emelyanov. We also thank L. Polyak from Ohio State University for fruitful comments. We thank E. V. Valiguras, K. A. Gruzdov, E. V. Zykina and V. F. Sapega for help with the laboratory work. Part of the analysis was completed with the support of the Russian Foundation for Fundamental Research (Project BONUS-INFLOW, grant RFFI-BONUS 08-05-92420). We thank the crew of RV 'Poseidon' and German colleagues for the opportunity to sample the investigated core.

\section{LITERATURE CITED}

Abelmann A (1985) Palökologische und ökostratigraphische Untersuchungen von Diatomeenassoziationen an holozänen Sedimenten der zentralen Ostsee. Ber Geolog Paläontolog Inst Univ Kiel 9:1-200

Andrén E (1999) Holocene environmental changes recorded by diatom stratigraphy in the southern Baltic Sea. Medd Stockh Univ Inst Geolog Geokem 302: 1-22

Berglund BE (1964) The postglacial shore displacement in eastern Blekinge, southeastern Sweden. Sver Geolog Unders Ser C599:1-47

Berglund BE, Sandegren P, Barnekow L, Hannon G, Jiang H, Skog G, Yu S (2005) Early Holocene history of the Baltic Sea, as reflected in coastal sediments in Blekinge, southeastern Sweden. Quat Int 130:111-139

Bitinas A, Damusyte A (2004) Littorina Sea at the Lithuanian maritime region. Pol Geol Inst Spec Pap 11:37-46

Björck S (1995) A review of the history of the Baltic Sea, 13.08.0 ka BP. Quat Int 27:19-40

Blazhchishin AI (1982) New data on the Baltic paleohydrology during Late Pleistocene. Baltica 7:173-178

Blazhchishin AI (1998) Paleogeography and evolution of LateQuaternary sedimentation in the Baltic Sea. Yantarny skaz, Kaliningrad (in Russian)

Blazhchishin AI, Davydova NN, Kvasov VV, Homutova VI (1974) Palynological and diatom analysis of 4 sediment core-sections from the southern and central Baltic. Baltica 3:119-126 (in Russian)

Emeis KC, Struck U, Blanz T, Kohly A, Voss M (2003) Salinity changes in the central Baltic Sea (NW Europe) over the last 10000 years. Holocene 13:413-423

Emelyanov EM (ed) (2002) Geology of the Gdansk Basin, Baltic Sea. Yantarny skaz, Kaliningrad
Eronen M (1983) Late Weichselian and Holocene shore displacement in Finland. In: Smith DE \& Dawson AG (eds) Shorelines and isostasy. Institute of British Geographers, Special Publication 16, Academic Press, New York, p 183-207

> Eronen M, Glückert G, Hatakka L, van de Plassche O, van der Plicht J, Rantala P (2001) Rates of Holocene isostatic uplift and relative sea-level lowering of the Baltic in SW Finland based on studies of isolation contacts. Boreas 30:17-30

Gelumbauskaite LŽ, Šeckus J (2005) Late Quaternary shore formations of the Baltic basins in the Lithuanian sector. Geologija 52:34-45

Grimm EC (1990) TILIA and TILIA-GRAF. PC spreadsheet and graphics software for pollen data. INQUA Working Group on Data-Handling Methods. Newsletter 4:5-7

Gritchuk VP, Zaklinskaya ED (1948) Analysis of fossilized pollen and spores and its application in paleogeography. Geographgiz, Moscow (in Russian)

Gudelis VK, Emelyanov EM (eds) (1976) Geology of the Baltic Sea. Mokslas, Vilnius (in Russian)

HELCOM (Helsinki Commission) (2007) Climate change in the Baltic Sea area. HELCOM Thematic Assessment 2007. Baltic Sea Environ Proc 111:1-49

Hughen KA, Baillie MGL, Bard E, Beck JW and others (2004) Marine04 marine radiocarbon age calibration, 0-26 cal Kyr BP. Radiocarbon 46:1059-1086

Jensen JB, Bennike O, Witkowski A, Lemke W, Kuijpers A (1999) Early Holocene history of the south-western Baltic Sea. Boreas 28:437-453

Kessel HJ, Davydova NN, Blazhchishin AI (1973) Pollen and diatoms of the core-sections from deepwater depressions of Baltic. Proc Acad Sci Est SSR Chem Geol 4:345-353 (in Russian)

Kleymenova GI, Homutova VI, Vishnevskaya EM (1979) Palynological and diatom analysis of the bottom sediments from the Baltic Sea. In: Gershanovich DE (ed) LateQuaternary history and sedimentation of the marginal and enclosed seas. Nauka, Moscow, p 40-46 (in Russian)

Krog H (1979) The Quaternary history of the Baltic, Denmark. In: Gudelis V, Königsson LK (eds) The Quaternary history of the Baltic. Uppsala University, p 207-217

Lampe R, Janke W (2004) The Holocene sea level rise in the Southern Baltic as reflected in coastal peat sequences. Pol Geol Inst Spec Pap 11:19-30

Lyahin YI (1994) Recent ecological conditions of CIS seas. RGGMI, St. Petersburg (in Russian)

Malyasova ES, Spiridonova EA (1983) Some questions concerning methods of palynological analysis of the Quaternary sediments of the North-West. In: Bartosh TD (ed) Palynology in geological studies of the Baltic region and Baltic Sea. Zinatne, Riga, p 9-13 (in Russian)

Mangerud J, Andersen ST, Berglund BE, Donner JJ (1974) Quaternary stratigraphy of Norden, a proposal for terminology and classification. Boreas 3:109-128

Matthäus W, Franck H (1992) Characteristics of major Baltic inflows - a statistical analysis. Cont Shelf Res 12:1375-1400

McCave IN (1984-1985) Mechanics of deposition of finegrained sediments from nepheloid layers. Geo-Mar Lett 4:243-245

McCave IN (1985) Sedimentology and stratigraphy of box cores from the HEBBLE site on the Nova Scotian continental rise. Mar Geol 66:56-89

Nilsson T (1964) Standartpollendiagramme und ${ }^{14} \mathrm{C}$ Datierungen aus dem Ageröds Mosse im mittleren Schonen. Lunds Univ Ärsskr 59:1-54

Nilsson E (1970) On Late-Quaternary history of Southern Sweden and the Baltic basin. Baltica 4:11-31 
Pedersen FB (1977) On dense bottom currents in the Baltic deep water. Nord Hydrol 8:297-316

Salvador A (1994) International stratigraphic guide. A guide of stratigraphic classification, terminology and procedure. International Union of Geological Sciences and and Geological Society of America, Washington, DC

Shabaev SV, Hlopnikov MM, Sokolov AV (eds) (2008) Fishery management cadastre of the cross-border waters of Russia (Kaliningrad Region) and Lithuania. Mishutkin Publisher, Kaliningrad (in Russian)

Shishkina OV, Pavlova GA, Bykova VS (1969) Geochemistry of halogens in the marine and oceanic sediments and pore waters. Nauka, Moscow (in Russian)

Snezhinsky VA (1951) Practical oceanography. GIMIZ, Leningrad (in Russian)

Sohlenius G, Sternbeck J, Andrén E, Westman P (1996) Holocene history of the Baltic Sea as recorded in a sediment core from the Gotland Deep. Mar Geol 134:183-201

Stelle VY, Avdeeva-Fedoseeva IY, Efimov AN, Savaitov AS (1976) Palynostratigraphy of the bottom sediments of the southern-eastern Baltic Sea. In: Bartosh TD (ed) Palynology in continental and marine geological studies. Zinatne, Riga, p 102-118 (in Russian)

Stigebrandt A (1987) A model for the vertical circulation of the Baltic deep water. J Phys Oceanogr 17:1772-1785

Terziev FS (ed) (1994) Hydrometeorology and hydrochemistry of USSR seas. III. Baltic Sea 2. Hydrochemical condi-

Submitted: December 1, 2009; Accepted: October 4, 2010 tions and oceanologic bases of formation of biological productivity. Hydrometeoizdat, St. Petersburg (in Russian)

Uscinowicz S (2003) Relative sea level changes, glacioisostatic rebound and shoreline displacement in the Southern Baltic. Pol Geol Inst Spec Pap 10

Witkowski A (1994) Recent and fossil diatom flora of the Gulf of Gdansk, the Southern Baltic Sea. Bibliotheca Diatomologica 28, Berlin-Stuttgart

Yakubovskaya IY, Stelle VY, Neimane MK (1983) Correlation of the Late Glacial spore-pollen spectra of the western Baltic Region and Baltic Sea. In: Bartosh TD (ed) Palynology in geological studies of the Baltic Region and Baltic Sea. Zinatne, Riga, p 58-60 (in Russian)

Yu SY, Berglund BE, Sandgren P, Fritz SC (2005) Holocene paleoecology along the Blekinge coast, southeast Sweden, and implications for climate and sea-level changes. Holocene 15:278-292

Zachowicz J (1995) Quaternary geological profiles (II). Pl. XVIII. In: Mojski JE, Dadlez R, Slowanska B, Uscinowicz S, Zachowicz J (eds) Geological atlas of the Southern Baltic, 1:500000. Polish Geological Institute, Sopot-Warszawa, p 1-62

Zachowicz J, Miotk-Szpiganowicz G, Kramarska R, Uscinowicz S, Zachowicz J, Przezdziecki P (2008) A critical review and reinterpretation of bio-, litho- and seismostratigraphic data of the southern Baltic deposits. Pol Geol Inst Spec Pap $23: 117-138$

Proofs received from author(s): May 25, 2011 